10. Tiwari, S. K., Rai, S. K., Bartarya, S. K., Gupta, A. K. and Negi, M., Stable isotopes $\left(\delta^{13} \mathrm{CDIC}, \delta \mathrm{D}, \delta^{18} \mathrm{O}\right)$ and geochemical characteristics of geothermal springs of Ladakh and Himachal (India): evidence for $\mathrm{CO}_{2}$ discharge in Northwest Himalaya. Geothermics, 2016, 64, 314-330.

11. Acharya, S. and Chaudhary, A., Effect of nutritional and environmental factors on cellulases activity by thermophilic bacteria isolated from hot spring. J. Sci. Indus. Res., 2011, 70, 142-148.

12. Ghosh, W., Mallick, S., Haldar, P. K., Pal, B., Maikap, S. C. and Gupta, S. K. D., Molecular and cellular fossils of a mat-like microbial community in geothermal boratic sinters. Geomicrobiol. $J ., 2012,29,879-885$.

13. Upadhyay, R., Middle Cretaceous carbonate build-ups and volcanic seamount in the Shyok suture, northern Ladakh, India. Curr. Sci., 2001, 81(6), 695-699.

14. Rao, D. R. and Rai, H., Geochemical studies of granitoids from Shyok tectonic zone of Khardung-Panamik section, Ladakh, India. J. Geol. Soc. India, 2009, 73, 553-566.

15. Montoya, J. P., Voss, M., Kahler, P. and Capone, D. G., A simple, high-precision, high-sensitivity tracer assay for $\mathrm{N}$ (inf2) fixation. Appl. Environ. Microbiol., 1996, 62, 986-993.

16. Antonio, R. M. and Bianchini Jr I., The effect of temperature on the glucose cycling and oxygen uptake rates in the Infernão Lagoon water, State of São Paulo, Brazil. Acta Sci., 2002, 24, 291-296.

17. Etxeberria, E., González, P., Tomlinson, P. and Pozueta-Romero, J., Existence of two parallel mechanisms for glucose uptake in heterotrophic plant cells. J. Exp. Bot., 2005, 56, 1905-1912.

18. Conde, C., Agasse, A., Glissant, D., Tavares, R., Gerós, H. and Delrot, S., Pathways of glucose regulation of monosaccharide transport in grape cells. Plant Physiol., 2006, 141, 1563-1577.

19. Morales-Sánchez, D., Martinez-Rodriguez, O. A., Kyndt, J. and Martinez, A., Heterotrophic growth of microalgae: metabolic aspects. World J. Microbiol. Biotechnol., 2015, 31, 1-9.

ACKNOWLEDGEMENTS. We thank the Director, BSIP, Lucknow and Dr Shailesh Agrawal (BSIP) for support. We also thank the NASA team for help while conducting the experiments, and Prof. M. S. Srinivasan and three anonymous reviewers for their useful comments to improve the manuscript.

Received 10 October 2018; revised accepted 30 October 2019

doi: $10.18520 / \mathrm{cs} / \mathrm{v} 118 / \mathrm{i} 4 / 644-648$

\section{Some aspects of seed dispersal by Asian elephants (Elephas maximus) in Kaudulla National Park, Sri Lanka}

\author{
Perera Mahesha ${ }^{1, *}$ and Vandercone Rajnish ${ }^{2,3}$ \\ ${ }^{1}$ National Research Council of Sri Lanka, Ground Floor, \\ Sri Lanka Institute of Architects Building, 120/07, Vidya Mawatha, \\ Colombo 07 (00700), Sri Lanka \\ ${ }^{2}$ Department of Biological Sciences, Faculty of Applied Sciences, \\ Rajarata University of Sri Lanka, Mihinthale 50300, Sri Lanka \\ ${ }^{3}$ The Ringling Center for the Study and Conservation of the Asian \\ Elephant, Rajarata University of Sri Lanka, Mihinthale 50300, \\ Sri Lanka
}

Our understanding of the qualitative and quantitative aspects of seed dispersal by Asian elephants is at its infancy. We explored some of these aspects at Kaudulla National Park, Sri Lanka, focusing on the germination potential of dispersed seeds, and the influence of gut passage on germination and latency in the seeds of Bauhinia racemosa. Seeds of ten species were dispersed and their germination potential was generally poor. However, gut passage significantly reduced the latency period of $B$. racemosa. Long-term research on frugivory, passage times of seeds and ranging behaviour will help develop wildlife management plans.

Keywords: Asian elephants, Bauhinia racemosa, latency, seed dispersal.

SEED dispersal has a profound impact on plant spatial structure, dynamics and community composition. The spatial distribution of seeds relating to their source plant sets the initial template for future processes that lead to plant recruitment ${ }^{1,2}$. As a result, seed dispersal has received significant attention of ecologists ${ }^{3}$. It has become the key to understanding several ecological phenomena such as community structure ${ }^{4,5}$, population dynamics ${ }^{6}$, evolutionary trade-offs ${ }^{7}$, ecological restoration ${ }^{8}$, interaction networks ${ }^{9}$ and biological invasions ${ }^{10}$. Animal-mediated seed dispersal is the most prevalent dispersal mechanism among plant species, as many plants possess highly adapted fruits that depend on vertebrates for recruitment ${ }^{11,12}$.

Endozoochoric seed dispersal, in which dispersal is effected by animals after passage through the gut, has been shown to reduce seed or seedling mortality due to higher predation rates, pathogen infection ${ }^{13}$ and sibling competition near the parent plant ${ }^{14}$, and aid colonization of disturbances or locating microhabitats suitable for establishment and growth ${ }^{15}$. For instance, seeds dispersed $45 \mathrm{~m}$ away from the mother plant of baboon wood (Virola surinamensis) recorded a 44-fold advantage in seed survivorship when compared to seeds deposited beneath the crown ${ }^{16}$. Over evolutionary time, animal seed dispersal

*For correspondence. (e-mail: maheshaper89@gmail.com) 
patterns define the gene flow among populations and the rate at which species are exposed to new selection regimes, aiding evolution in novel environments ${ }^{17}$.

The framework of seed disperser effectiveness (SDE) proposed by Schupp et al., for evaluating the contribution of individual dispersal agents to plant fitness, and to better link studies of seed dispersal and plant demography, consists of two main components - the quantitative aspect and the qualitative aspect. Many studies on the visitation of fruiting plants focus on the quantitative aspect of seed dispersal ${ }^{18}$. Studies on the ranging behaviour and gut passage effects on germination focus on the qualitative aspects of seed dispersal ${ }^{19}$. Seldom have seed dispersal studies addressed both quantitative and qualitative elements which are essential for a comprehensive assessment of $\mathrm{SDE}^{20}$.

Megafaunal seed dispersers are of significant interests to ecologists as they have the capacity to ingest fruits that are not consumed by other frugivores and also deliver more seeds per defecation event over longer distances ${ }^{21}$. Elephants, one of the few remaining extant megafauna ${ }^{22}$, possess a large gape which ensures that their diet is not constrained by fruit size ${ }^{23}$. Owing to their demanding energy requirements and hindgut digestion, elephants maintain an extremely diverse diet and also consume fruits $^{24,25}$. Furthermore, they range over a vast area and also have lengthy gut passage times which enhance their potential to disperse ingested seeds well away from the parent plant ${ }^{26}$. Elephants also release large amounts of viable seeds ${ }^{27}$. Additionally, their dung provides favourable germination conditions in terms of moisture for germination and nutrient availability for seedling growth ${ }^{28,29}$. Together these factors reinforce the role of elephants as prodigious seed-dispersers ${ }^{23}$.

While several studies have analysed the seed dispersal potential of elephants majority of them have focused on African elephants (Loxodonta africana) $)^{12,30-33}$. Comparatively, only few studies have focused on frugivory and seed dispersal by Asian elephants ${ }^{23,34,35}$. These studies show that there is considerable variation in frugivory and seed dispersal potential between African and Asian elephants, and also between populations of a given species. For instance, Asian elephants in southeastern Sri Lanka dispersed seeds of 69 plant species ${ }^{29}$, while elephants in the Khao Yai National Park, Thailand dispersed only nine species ${ }^{28}$. Hence, a few studies are insufficient to evaluate the seed dispersal potential of Asian elephants.

Furthermore, studies on elephant seed dispersal and feeding ecology in Sri Lanka indicate that Maila (Bauhinia racemosa) is a common dietary item of elephants ${ }^{34,36,37}$. The dry-zone forests in Sri Lanka are dominated by plants species of the family Euphorbiaceae ${ }^{38}$. B. racemosa (Fabaceae) appears to be the dominant tree species in habitats favoured by elephants ${ }^{39}$. Hence, it is possible that $B$. $r a$ cemosa dispersal and establishment is facilitated by elephants. An understanding of the impact of elephants on the vegetation structure and composition is important in formulating conservation management plans.

Hence, the objective of this study was to determine the seed dispersal potential of Asian elephants in the Kaudulla National Park, in the dry zone of Sri Lanka, by evaluating both quantitative and qualitative aspects of seed dispersal. We specifically studied the diversity of plant species, and the quantity of seeds and germination potential of seeds dispersed by elephants, including B. racemosa. Furthermore, only few studies have been carried out on the feeding ecology $\mathrm{y}^{36,37,40}$ in Sri Lanka and hence, this study also contributes to the understanding of feeding ecology of the Asian elephants in Sri Lanka.

The study was conducted in the Kaudulla National Park, located on the fringe of the ancient Kaudulla Tank $\left(8.1611^{\circ} \mathrm{N}, 80.9050^{\circ} \mathrm{E}\right)$ that lies within the Polonnaruwa District of the North-Central Province in Sri Lanka (Figure 1). The Park covers a total area of $66.56 \mathrm{~km}^{2}$. Vegetation in the region can be subdivided structurally into tropical dry mixed evergreen forest, grassland and riverine forest. Tree species such as palu (Manilkara hexan$d r a$ ), sandun (Chloroxylon swietenia) and milla (Vitexa ltissima). Kukuruman (Randia dumetorum), and wara (Calotropis gigantea) are common in the shrub layer. The grasslands are dominated by grasses such as iluk (Imperata cylindrica), and gini tana (Panicum maximum). The mean annual rainfall in the region ranges between 1500 and $2000 \mathrm{~mm}$, and is received mostly during December to February. The monthly temperature ranges between a mean daily maximum of $34.5^{\circ} \mathrm{C}$ and a mean daily minimum of $20.6^{\circ} \mathrm{C}$.

Several visits were made to the Kaudulla National Park from July to September 2015, during the fruiting season in the dry zone $\mathrm{e}^{38}$. Jeep trails, which are more or less concentrated in the grasslands around the Kaudulla Reservoir, were traversed in a vehicle from around 7.00 to 11.00 AM and 3.00 to 5.30 PM. When elephant herds were encountered, they were followed until they retreated back into the forest. The elephants within the Park are habituated to the presence of vehicles and could be approached to within a distance of $50 \mathrm{~m}$, without showing any signs of agitation or flight during the study period. Three boli were collected from each dung pile soon after defecation. We considered boli scattered within a radius of $3 \mathrm{~m}$ of a pile to be part of a single pile. We managed to collect a total of 66 dung piles during the study period. The boli were dried and then shredded by hand using rubber gloves to determine the presence/absence of seeds. Recovered intact seeds were counted and identified using voucher samples extracted from ripe fruits collected at the base of fruiting trees.

All visually undamaged seeds of all plant species encountered in the dung were subjected to germination trials to assess their viability and germination potential. The number of seeds subjected to testing was dependent on their availability. The seeds were placed on a wet 


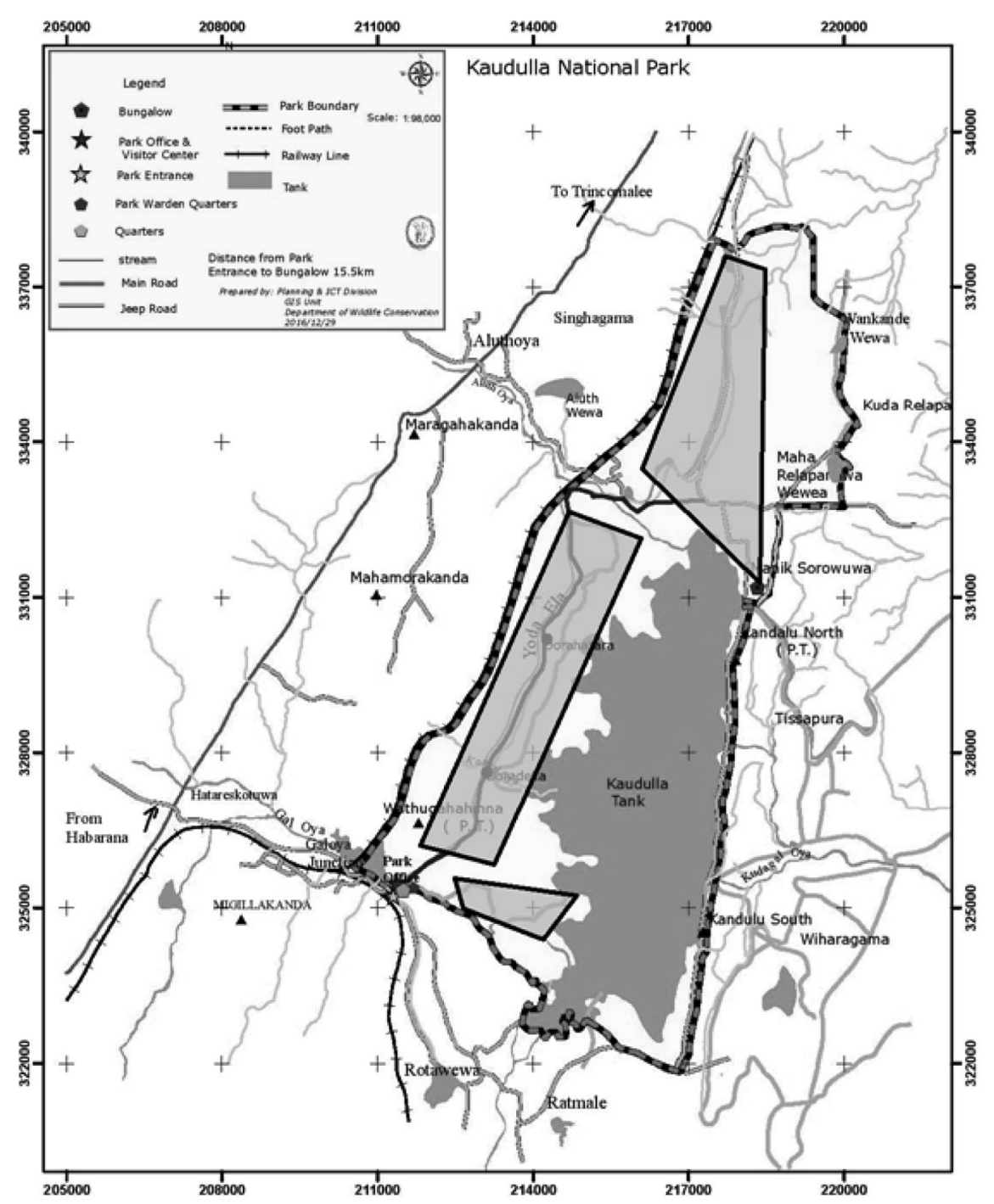

Figure 1. Map showing the study area. Red grids indicate sampled area (source: Department of Wildlife Conservation, Sri Lanka).

floristic foam held in plastic containers under partial shade in a plant house, and checked daily for germination $^{41}$. They were watered whenever the floristic foam became dry to touch.

Germination trials using seeds of maila (B. racemosa) were carried out to determine differences in the germination success and latency period between ingested seeds collected from elephant dung and fresh seeds from ripe fruit collected under the fruiting trees. Bauhinia seeds were chosen as they were highly abundant in elephant dung and had a higher germination success in comparison to other species. In total, 60 ingested seeds and 40 fresh seeds were used during the course of two germination trials. Some Bauhinia seeds were not included in the trial due to the presence of bored holes in the outer seed coat. Germination was monitored for a period of three weeks, as delineated by Samansiri and Weerakoon ${ }^{34}$. Germination success and latency period of fresh seeds and in- gested seeds were recorded. Appearance of the sprout was considered as germination success and time taken for appearance of the sprout was considered as the latency period.

Pile-wise seed evenness, richness and diversity were evaluated using the Shannon-Weiner index and Simpson index. The impact of gut passage on germination success was tested using a chi-square test of independence, while differences in latency period between the experiments and controls were determined using $t$-tests. All statistical analysis was performed using SPSS 23.0 at a significance level $\alpha=0.05$.

Relatively small percentage of dung piles (37.9) contained seeds. Seeds from ten plant species were recovered from the 66 elephant dung piles (Table 1). Six seeds were identified to species level and one to genus level. Two were identified to only the family level (species 2 and 4), while one remained unidentified (species 5) (Figure 2). 


\section{RESEARCH COMMUNICATIONS}

Table 1. Frequency, abundance and germination potential of seeds recorded in the dung of Asian elephants (Elephas maximus) at Kaudulla National Park, Sri Lanka

\begin{tabular}{|c|c|c|c|c|c|c|c|}
\hline Family & Scientific name & $\begin{array}{l}\text { Vernacular } \\
\text { name }\end{array}$ & $\begin{array}{c}\text { Number of } \\
\text { piles with seeds }\end{array}$ & $\begin{array}{c}\text { Dung piles } \\
\text { with seeds (\%) }\end{array}$ & $\begin{array}{l}\text { Total number } \\
\text { of seeds }\end{array}$ & $\begin{array}{l}\text { Mean number of } \\
\text { seeds per bolus }\end{array}$ & $\begin{array}{l}\text { Germination } \\
\text { success }(\%)\end{array}$ \\
\hline Cucurbitaceae & Cucurbita sp. & Wattaka & 1 & 1.5 & 4 & 1.3 & 0 \\
\hline \multirow[t]{2}{*}{ Fabaceae } & Bauhinia racemosa & Maila & 5 & 7.5 & 83 & 5.5 & 41.7 \\
\hline & Mimosa pudica & Nidikumba & 1 & 1.5 & 2 & 0.7 & 0 \\
\hline Moraceae & Artocarpus heterophyllus & Kos & 2 & 3.0 & 15 & 2.5 & 66.7 \\
\hline \multirow[t]{2}{*}{ Solanaceae } & Unidentified species 2 & & 11 & 16.7 & 463 & 13.9 & 5 \\
\hline & Solanum melongena & Ela batu & 1 & 1.5 & 3 & 0.7 & 50 \\
\hline Scrophulariaceae & Unidentified species 4 & & 1 & 1.5 & 13 & 5.3 & 0 \\
\hline Unknown & Unidentified species 5 & & 7 & 10.6 & 17 & 0.8 & 0 \\
\hline
\end{tabular}
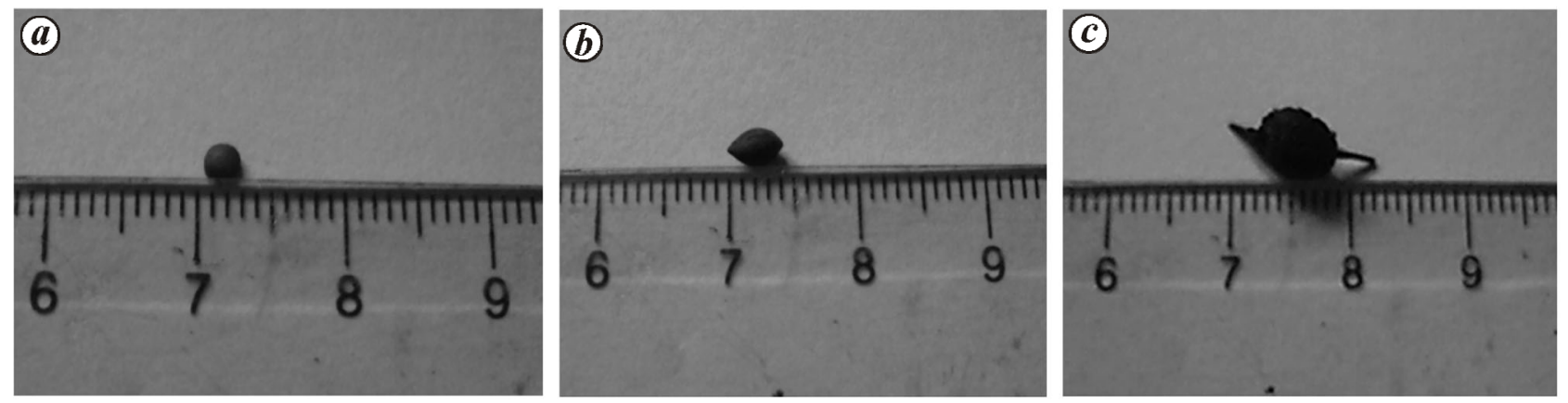

Figure 2. $\boldsymbol{a}$, Unidentified species $2 ; \boldsymbol{b}$, unidentified species $4 ; \boldsymbol{c}$, unidentified species 5 .

Seed species recovered from elephant dung were relatively small in size, ranging from 3 to $34 \mathrm{~mm}$. The largest seeds were those of Artocarpus heterophyllus. Majority of the seeds were from herbaceous plant species and three of the identified plant species (Cucurbita sp., Oryza sativa, Solanum melongena) belonged to cultivated plant varieties.

The highest germination success was shown by Artocarpus heterophyllus (66.7\%), while Cucurbita sp., Mimosa pudica, species 4 and 5 did not germinate at all. Among the $60 \mathrm{~B}$. racemosa seeds recovered from the dung, 25 (41.7\%) germinated. The average time taken for germination was 11 days (range $=3-21$ ). Of the 40 fresh B. racemosa seeds collected from mature fruit, $16(40 \%)$ germinated with an average germination time of 17 days (range $=10-21)$. There was no statistically significant difference in the germination success between ingested and fresh seeds $\left(x^{2}=0.028, \mathrm{~d} f=1, P=0.868\right)$. However, difference in the latency period between ingested and fresh seeds was statistically significant $(t=2.467$, $\left.\mathrm{d} f=24, n_{1}=11, n_{2}=15, P=0.021\right)$.

In this study we recorded seeds from ten plant species distributed among relatively low number of dung boli $(37.9 \%)$, suggesting low level of frugivory in comparison to African forest elephants. Our findings are in agreement with other reports on seed dispersal of Asian elephant populations (Table 2). There was also no evidence of any plant entirely dependent on Asian elephants for seed dispersal. The presence of seeds of cultivated species is most likely due to crop raiding by elephants. The abundance of certain seeds such as $B$. racemosa could be due to their abundance in elephant habitats ${ }^{39}$.

The variation of frugivory between African and Asian elephants could be attributed to differences in habitat quality and availability of food resources in the two regions the evolutionary history of the two species. African elephants occupy tropical rain forests, tropical grasslands and savannahs with high diversity of plants which produce large seeds dependent on animal dispersal ${ }^{42}$. In comparison, Asian elephants mostly occupy savannawoodland habitats (i.e. seasonally dry forests) ${ }^{43}$, where a greater number of species fruit only during the rainy sea$\operatorname{son}^{40}$. In Sri Lanka, they inhabit dry evergreen and thornscrub forests in the dry zone ${ }^{45}$ which are less diverse than wet zone forests ${ }^{46}$. In the dry forests of Sri Lanka, immature leaf availability is highest during the wet season (November-January), and fruit availability during the dry season (May-September) ${ }^{47}$. Moreover, seed dispersal by elephants in Sri Lanka most likely occurs the process of herbivory, when fruits may be ingested by chance along with foliage and twigs, rather than preference ${ }^{48}$.

Furthermore, elephants have inhabited Africa much longer than $\mathrm{Asia}^{49}$, giving African flora more time to evolve physical and chemical adaptations to facilitate 
Table 2. Diversity of seeds found in elephant dung

\begin{tabular}{|c|c|c|c|c|c|c|}
\hline Elephant taxon & Country & Site & $\begin{array}{l}\text { Number of dung } \\
\text { piles sampled }\end{array}$ & $\begin{array}{c}\% \text { Containing } \\
\text { seeds }\end{array}$ & $\begin{array}{l}\text { No. of } \\
\text { species }\end{array}$ & Reference \\
\hline \multirow[t]{4}{*}{ AFE } & Gabon & Institute for Research in Tropical Ecology & 104 & 99 & 32 & 12 \\
\hline & Zaire & Kahuzi-Beiga & 203 & & 14 & 30 \\
\hline & Cameroon & Banyang-Mbo & 2387 & & 50 & 32 \\
\hline & Rep Coongo & Ndoki & 855 & 94 & 96 & 33 \\
\hline ASE & Zimbabwe & Hwange & 329 & 80 & 28 & 31 \\
\hline \multirow{4}{*}{ AAE } & Sri Lanka & Northwestern & 145 & 74 & 44 & 34 \\
\hline & Sri Lanka & Southeastern & 479 & 93.5 & 69 & 29 \\
\hline & & & 721 & 61.85 & 26.6 & \\
\hline & India & Silent Valley & 384 & 28.9 & 21 & 35 \\
\hline
\end{tabular}

AFE, African forest elephant; ASE, African savannah elephant; AAE, Asian elephant.

elephant-based seed dispersal. For example, plant species such as Balanites wilsoniana bear large fruits with exceptionally large and hard seeds with a toxic substance that cannot be dispersed by any dispersers other than elephants $^{12,50}$.

While $A$. heterophyllus recorded the highest germination success $(66.7 \%)$ in the present study, certain other species did not show signs of germination. Our results are consistent with the mixed results of a previous study on ingestion by Asian elephants, which indicates mild positive, neutral or negative effects on seed germination ${ }^{23}$. Ingested $B$. racemosa seeds also showed a neutral response regarding germination success when compared to that of the control seeds, whose seed coats were not subjected to the digestive process. However, the latency period or the time taken for germination of $B$. racemosa seeds consumed by elephants was significantly lower than in control seeds. Similar observations were made during germination trials performed in a study on seed dispersal capability of African elephant, where no difference was observed in overall germination, although the germination time of ingested seeds was generally shorter $^{32}$.

It is generally argued that increased germination success and reduced latency period is a benefit of seed ingestion $^{51}$. Factors such as mechanical or chemical scarification of seed coat, separation of seeds from the seed pulp and the effect of faecal material surrounding the seed could increase germination and reduce latency of ingested seeds ${ }^{52}$. Germination of $B$. racemosa waterimpermeable seed coat has been shown to improve through mechanical scarification, and sulphuric acid and wet-heat treatments ${ }^{53}$. Hence, it is likely that mechanical abrasion of the highly adapted molar teeth of elephants, partial digestion by the acids in their gastric juice and the heat action in their guts ${ }^{54}$ remove seed dormancy and reduce the latency period in B. racemosa. The timing of germination is a critical factor in the life cycle of plants, for it determines plant performance and success as early emerging seedlings can outcompete the later emerging ones $^{55}$. The reduction in the latency period of $B$. racemosa seeds, their relatively high abundance in dung piles and their resistance to elephant browsing ${ }^{56}$ and fire ${ }^{39}$ could result in this species becoming dominant and invasive in habitats with elephants.

However, changes in landscape structure and management practices have known to alter the ecological function of seed dispersers; turning their positive role of maintenance of biodiversity into a negative one of spreading of invasive plants ${ }^{57}$. Since elephants disperse a large quantity of $B$. racemosa seeds and also reduce latency, wildlife management practices such as mass translocation and confinement of animals to national parks, which increase elephant populations, may have long-term consequences for vegetation diversity in these parks. The fact that elephants are capable of dispersing certain plant species more effectively than others should be taken into consideration during park management, as the scale at which elephants move and disperse seeds makes the potential impact high ${ }^{29,58}$

Our study shows that although elephant gut passage is not essential for germination, it plays an important role to ensure the success and perpetuation of certain species. Further, long-term research on frugivory, gut passage times of seeds and ranging behaviour is essential to determine the seed dispersal potential and patterns of Asian elephant populations in Sri Lanka, and to inform elephant management and conservation practices.

1. Schupp, E. W., Jordano, P. and Gomez, J. M., Seed dispersal effectiveness revisited: a conceptual review. New Phytologist, 2010, 188(2), 333-353.

2. Nathan, R. and Muller-Landau, H. C., Spatial patterns of seed dispersal, their determinants and consequences for recruitment. Trends Ecol. Evol., 2000, 15(7), 278-285.

3. Bullock, J. M. and Nathan, R., Plant dispersal across multiple scales: linking models and reality. J. Ecol., 2008, 96(4), 567568.

4. Cain, M. L., Milligan, B. G. and Strand, A. E., Long-distance seed dispersal in plant populations. Am. J. Bot., 2000, 87(9), $1217-$ 1227. 


\section{RESEARCH COMMUNICATIONS}

5. Levine, J. M. and Murrell, D. J., The community-level consequences of seed dispersal patterns. Annu. Rev. Ecol., Evol. Syst., 2003, 34(1), 549-574.

6. Spiegel, O. and Nathan, R., Incorporating dispersal distance into the disperser effectiveness framework: frugivorous birds provide complementary dispersal to plants in a patchy environment. Ecol. Lett., 2007, 10(8), 718-728.

7. Clark, J. S., LaDeau, S. and Ibanez, I., Fecundity of trees and the colonization-competition hypothesis. Ecol. Monogr., 2004, 74(3), $415-442$.

8. Nuttle, T. and Haefner, J. W., Design and validation of a spatially explicit simulation model for bottomland hardwood forests. Ecol. Modell., 2007, 200(1-2), 20-32.

9. Bascompte, J. and Jordano, P., Plant-animal mutualistic networks: the architecture of biodiversity. Annu. Rev. Ecol., Evol. Syst., 2007, 38, 567-593.

10. Buckley, Y. M. et al., Management of plant invasions mediated by frugivore interactions. J. Appl. Ecol., 2006, 43(5), 848-857.

11. Howe, H. F. and Smallwood, J., Ecology of seed dispersal. Annu. Rev. Ecol. Syst., 1982, 13(1), 201-228.

12. Gautier-Hion, A. et al., Fruit characters as a basis of fruit choice and seed dispersal in a tropical forest vertebrate community. Oecologia, 1985, 65(3), 324-337.

13. Howe, H. F., Aspects of variation in a neotropical seed dispersal system. In Frugivory and Seed Dispersal: Ecological and Evolutionary Aspects, Springer, Dordrecht, 1993, pp. 149-162.

14. McCall, C., Mitchell-Olds, T. and Waller, D. M., Fitness consequences of out crossing in Impatiens capensis: tests of the frequency-dependent and sib-competition models. Evolution, 1989, 43(5), 1075-1084.

15. Reid, N., Dispersal of misteltoes by honeyeaters and flower peckers: components of seed dispersal quality. Ecology, 1989, 70(1), $137-145$.

16. Howe, H. F., Schupp, E. W. and Westley, L. C., Early consequences of seed dispersal for a neotropical tree (Virola surinamensis). Ecology, 1985, 66(3), 781-791.

17. Linhart, Y. B. and Grant, M. C., Evolutionary significance of local genetic differentiation in plants. Annu. Rev. Ecol. Syst., 1996, 27(1), 237-277.

18. Howe, H. F. and Vande Kerckhove, G. A., Removal of wild nutmeg (Virola surinamensis) crops by birds. Ecology, 1981, 62(4), 1093-1106.

19. Ortiz-Pulido, R. and Rico-Gray, V., Seed dispersal of Bursera fagaroides (Burseraceae): the effect of linking environmental factors. Southwest. Nat., 2006, 51(1), 11-21.

20. Schupp, E. W., Jordano, P. and Gomez, J. M., Seed dispersal effectiveness revisited: a conceptual review. New Phytologist, 2010, 188(2), 333-353.

21. Janzen, D. H. and Martin, P. S., Neotropical anachronisms: the fruits the gomphotheres ate. Science, 1982, 215(4528), 19-27.

22. Owen-Smith, R. N., Megaherbivores: The influence of very large body size on ecology. Cambridge Studies in Ecology, Cambridge Press, Cambridge, 1988.

23. Campos-Arceiz, A. and Blake, S., Megagardeners of the forest-the role of elephants in seed dispersal. Acta Oecol., 2011, 37(6), 542553.

24. Chen, J., Deng, X., Zhang, L. and Bai, Z., Diet composition and foraging ecology of Asian elephants in Shangyong, Xishuangbanna, China. Acta Ecol. Sin., 2006, 26(2), 309-316.

25. Campos-Arceiz, A., Lin, T. Z., Htun, W., Takatsuki, S. and Leimgruber, P., Working with mahouts to explore the diet of work elephants in Myanmar (Burma). Ecol. Res., 2008, 23(6), 1057-1064.

26. Dudley, J. P., Seed dispersal of Acacia erioloba by African bush elephants in Hwange National Park, Zimbabwe. Afr. J. Ecol., 1999, 37(4), 375-385.

27. Sivaganesan, N. and Johnsingh, A. J. T., Food resources crucial to the wild elephants in Mudumalai wildlife sanctuary, South India.
A Week with Elephants, Bombay Natural History Society, Bombay and Oxford University Press, New Delhi, 1995, pp. 405-423.

28. Kitamura, S., Yumoto, T., Poonswad, P. and Wohandee, P., Frugivory and seed dispersal by Asian elephants, Elephas maximus, in a moist evergreen forest of Thailand. J. Trop. Ecol., 2007, 23(3), 373-376.

29. Campos-Arceiz, A., Larrinaga, A. R., Weerasinghe, U. R., Takatsuki, S., Pastorini, J., Leimgruber, P., Fernando, P. and Santamaría, L., Behavior rather than diet mediates seasonal differences in seed dispersal by Asian elephants. Ecology, 2008, 89(10), 2684-2691.

30. Yumoto, T., Maruhashi, T., Yamagiwa, J. and Mwanza, N., Seeddispersal by elephants in a tropical rain forest in Kahuzi-Biega National Park, Zaire. Biotropica, 1995, 27(4), 526-530.

31. Dudley, J. P., Seed dispersal by elephants in semiarid woodland habitats of Hwange National Park, Zimbabwe 1. Biotropica, 2000, 32(3), 556-561.

32. Nchanji, A. C. and Plumptre, A. J., Seed germination and early seedling establishment of some elephant-dispersed species in Banyang-Mbo Wildlife Sanctuary, south-western Cameroon. J. Trop. Ecol., 2003, 19(03), 229-237.

33. Blake, S., Deem, S. L., Mossimbo, E., Maisels, F. and Walsh, P., Forest elephants: tree planters of the Congo. Biotropica, 2009, 41(4), 459-468.

34. Samansiri, K. A. P. and Weerakoon, D. K., A study on the seed dispersal capability of Asian elephants in the northwestern region of Sri Lanka. Gajah, 2008, 28, 19-24.

35. Jothish, P. S., Frugivory and seed dispersal of woody species by the Asian elephant (Elephas maximus) in a mid-elevation tropical evergreen forest in India. J. Trop. Ecol., 2013, 29(2), 181-185.

36. McKay, G. M., Behavior and Ecology of the Asiatic Elephant in Southeastern Ceylon (No. 125), Smithsonian Institution Press, Washington, DC, 1973.

37. Ishwaran, N., Elephant and woody-plant relationships in Gal Oya, Sri Lanka. Biol. Conserv., 1983, 26(3), 255-270.

38. Vandercone, R., Dietary Shifts, Niche Relationships and Interspecific Competition in Sympatric Grey Langur (Semnopithecus entellus) and Purple-faced Langur (Trachypithecus vetulus) in Sri Lanka. Ph D Thesis, Washington University, St Louis, 2011.

39. Jayasingam, T., Balasubramaniam, S. and Vivekanantharajah, S., Vegetation survey of the Wasgomuwa National Park: reconnaissance. Vegetatio, 1992, 101(2), 171-181.

40. Vancuylenberg, B. W. B., Feeding behaviour of the Asiatic elephant in south-east Sri Lanka in relation to conservation. Biol. Conserv., 1977, 12(1), 33-54.

41. Valenta, K. and Fedigan, L. M., Effects of gut passage, feces, and seed handling on latency and rate of germination in seeds consumed by capuchins (Cebus capucinus). Am. J. Phys. Anthropol.: Off. Publ. Am. Assoc. Phys. Anthropol., 2009, 138(4), 486-492.

42. Moles, A. T. et al., Global patterns in seed size. Global Ecol. Biogeogr., 2007, 16(1), 109-116.

43. Leimgruber, P., Gagnon, J. B., Wemmer, C., Kelly, D. S., Songer, M. A. and Selig, E. R., Fragmentation of Asia's remaining wildlands: implications for Asian elephant conservation. In Animal Conservation Forum, Cambridge University Press, 2003, vol. 6, No. 4, pp. 347-359.

44. Griz, L. M. S. and Machado, I. C. S., Fruiting phenology and seed dispersal syndromes in caatinga, a tropical dry forest in the northeast of Brazil. J. Trop. Ecol., 2001, 17(2), 303-321.

45. Fernando, P., Elephants in Sri Lanka: past, present, and future. Loris, 2000, 22, 38-44.

46. Ministry of Forestry and Environment. Biodiversity conservation in Sri Lanka: A Framework for Action, MFE, Sri Lanka, 1999.

47. Vandercone, R. P., Dinadh, C., Wijethunga, G., Ranawana, K. and Rasmussen, D. T., Dietary diversity and food selection in Hanuman langurs (Semnopithecus entellus) and purple-faced langurs (Trachypithecus vetulus) in the Kaludiyapokuna Forest Reserve in 
the dry zone of Sri Lanka. Int. J. Primatol., 2012, 33(6), 1382 1405 .

48. Campos-Arceiz, A., The ecological role of Asian elephants as agents of seed dispersal in human-dominated landscapes. Doctoral dissertation, The University of Tokyo, 2009.

49. Shoshani, J., Understanding proboscidean evolution: a formidable task. Trends Ecol. Evol., 1998, 13(12), 480-487.

50. Babweteera, F., Savill, P. and Brown, N., Balanites wilsoniana: regeneration with and without elephants. Biol. Conserv., 2007, 134(1), 40-47.

51. Krefting, L. W. and Roe, E. I., The role of some birds and mammals in seed germination. Ecol. Monogr., 1949, 19(3), 269-286.

52. Traveset, A. and Verdu, M., A meta-analysis of the effect of gut treatment on seed germination. In Seed Dispersal and Frugivory: Ecology, Evolution, and Conservation, CABI, 2002, vol. 22, pp. 339-350.

53. Prasad, P. and Nautiyal, A. R., Physiology of germination in Bauhinia: involvement of seed coat in inhibition of germination in B. racemosa Lam. seeds. Seed Sci. Technol. (Switzerland), 1996, 24(2), 305-308.

54. Traveset, A., Effect of seed passage through vertebrate frugivores' guts on germination: a review. Perspect. Plant Ecol. Evol. Syst., 1998, 1(2), 151-190.

55. Weaver, S. E. and Cavers, P. B., The effects of date of emergence and emergence order on seedling survival rates in Rumex crispus and R. obtusifolius. Can. J. Bot., 1979, 57, 730-738.

56. Fernando, P. and Leimgruber, P., Asian elephants and seasonally dry forests. The Ecology and Conservation of Seasonally Dry Forests in Asia, Smithsonian Institution Scholarly Press, Washington, DC, 2011, pp. 151-163.

57. Richardson, D. M., Allsopp, N., D’antonio, C. M., Milton, S. J. and Rejmánek, M., Plant invasions - the role of mutualisms. Biol. Rev., 2000, 75(1), 65-93.

58. Bal, P., Nath, C. D., Nanaya, K. M., Kushalappa, C. G. and Garcia, C., Elephants also like coffee: trends and drivers of humanelephant conflicts in coffee agroforestry landscapes of Kodagu, Western Ghats, India. Environ. Manage., 2011, 47(5), 789-801.

ACKNOWLEDGEMENTS. We thank the Department of Wildlife Conservation in Sri Lanka for permission to conduct this research. We also thank Krishantha Sameera de Zoysa and others who assisted with field work, and Ringling Bros (Center for Elephant Conservation) for funds.

Received 17 October 2018; revised accepted 30 September 2019

doi: $10.18520 / \mathrm{cs} / \mathrm{v} 118 / \mathrm{i} 4 / 648-654$

\section{Reliability modelling on drivers' decision during the yellow phase of a signal intersection}

\author{
Sabyasachi Biswas ${ }^{1, *}$ and Indrajit Ghosh ${ }^{2}$ \\ ${ }^{1}$ Department of Civil Engineering, National Institute of Technology, \\ Jamshedpur 832 014, India \\ ${ }^{2}$ Department of Civil Engineering, Indian Institute of Technology \\ Roorkee, Roorkee 247 667, India
}

During the yellow phase starts of a traffic signal, the drivers are unable to take quick decisions whether to stop or cross the signal-controlled intersection. This dilemma zone (DZ) can cause a mix-up among drivers during the yellow phase and may lead to accidents. In the present study we use a $\mathrm{DZ}$ prediction model for analysis. In this study, approach speed, acceleration/ deceleration of different vehicle categories, distance to stop line, offset of yellow time, and presence or absence of countdown timer are considered as the main factors influencing the model. In order to address several drawbacks associated with traditional regressionbased models, a kriging-based surrogate model has been developed to explore the drivers' behaviour during the yellow phase.

Keywords: Dilemma zone, kriging model, traffic intersection, yellow phase drivers.

IN India, the highest number of road casualties occur at signal intersections. According to a Ministry of Road Transport and Highways (MoRTH), Government of India report road accidents account for $37.8 \%$ of total accidents ${ }^{1}$. Previous studies observed that the dilemma zone (DZ) is one of the most significant parameters affecting the safety at an intersection ${ }^{2,3}$.

A driver needs to take quick decision based on his experience while approaching the signalized intersections during the initial yellow phase. He needs to decide whether to cross the intersection or halt before the stop line. The virtual area immediately before the stop line is the $\mathrm{DZ}^{4}$, where drivers get confused whether to cross or stop at the intersection. In addition, drivers have a small response time to react. This results in red-light violations (RLVs) leading to safety problems at the intersections during the yellow phase.

To reduce problems associated with the DZ, development of drivers' decision prediction models has gained huge attention in the last few decades. The evolution of intelligent transportation systems (ITSs) has led to the effectiveness of these models. The system of sensors can be used in these models to accurately predict the drivers' decision at the intersections and prevent accidents like rear-end and angular collisions.

*For correspondence. (e-mail: sabyasachibiswas01@gmail.com) 